\title{
Potential Recognition Layer in Electrochemical Sensor: A Comparative Characterization of p-Cyano Schiff Base Compounds
}

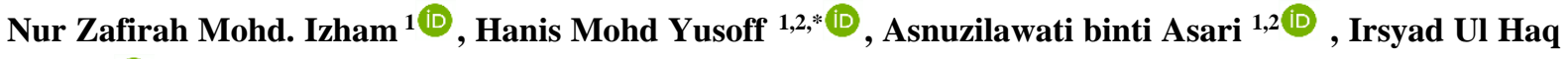 \\ Bhat ${ }^{1,2}$ (D) \\ 1 Faculty of Sciences and Marine Environment, Universiti Malaysia Terengganu, 21030 Kuala Nerus, Terengganu, Malaysia \\ 2 Advanced Nano Materials (ANoMa) Research Group, Faculty of Science and Marine Environment, Universiti Malaysia \\ Terengganu, 21030 Kuala Nerus, Terengganu, Malaysia \\ * Correspondence: hanismy@umt.edu.my (H.M.Y.);
}

Scopus Author ID: 56380269300

Received: 5.04.2021; Revised: 11.05.2021; Accepted: 14.05.2021; Published: 10.06.2021

\begin{abstract}
The effective conjugation of electrons in aromatic Schiff bases has been utilized as an electrochemical sensor in forensic, pharmaceutical and environmental applications. The use of the Schiff base enhances the sensitivity and selectivity of the sensor. In this study, p-cyano Schiff base derived from 4-(4-aminostyryl)benzonitrile and three different aldehydes were synthesized. The spectroscopic techniques via Fourier transform-infrared spectroscopy (FT-IR), Uv-Vis spectrophotometry and Nuclear Magnetic Resonance (NMR) of ${ }^{1} \mathrm{H}$ and ${ }^{13} \mathrm{C}$ were used for structural elucidation resulted compounds. The targeted p-cyano Schiff base showed a clear imine $(\mathrm{C}=\mathrm{N})$ stretching vibration band at $1681-1708 \mathrm{~cm}^{-1}, \mathrm{n} \rightarrow \pi^{*}$ electronic transition at 355-360 $\mathrm{nm}$ in UV-Vis and a singlet: 8.34-8.39 ppm and 118.07-119.09 ppm for ${ }^{1} \mathrm{H}$ and ${ }^{13} \mathrm{C}$ NMR, respectively, supporting the formation of Schiff bases. The application of Schiff base as spacer in electrochemical DNA (E-DNA) sensor has not been much research done on it so far. The obtained compounds are potentially valuable for electrochemical-DNA sensor study in the future.
\end{abstract}

Keywords: cyano; stilbene; Schiff base; spacer; linker; recognition layer; E-DNA sensor

(C) 2021 by the authors. This article is an open-access article distributed under the terms and conditions of the Creative Commons Attribution (CC BY) license (https://creativecommons.org/licenses/by/4.0/).

\section{Introduction}

There are several methods of attachment for electrode surface modification in biosensors. Among them is a self-assembled monolayer (SAM), which is an organized layer of molecules that spontaneously forms on a solid surface, mainly for binding of biorecognition elements such as deoxyribonucleic acid (DNA), proteins and antibodies onto metal substrates [1-3]. SAM has been studied extensively and one of the most widely examined SAM as a spacer in gold electrode modification is alkanethiol, attributed to its remarkably stable interactions between spacers and metal substrates [4-12]. 3-mercaptopropionic acid (MPA) and 11-mercaptoundecanoic acid (MUA) are among the most popular alkanethiol spacers that are suitable for their use as electrochemical DNA [13,14]. However, there are several limitations encountered in S-Au monolayers [9,15-17]. Alkanethiols were reported as unstable in long-term storage and elevated temperature $[13,18,19]$ and high salt concentration. Plus, they are also oxidative at ambient temperature [13,19,20], affecting sensor properties and performance. 
Schiff base (SB), generally known as imines or azomethines, has been applied in a broad range of applications in various studies (e.g., material science, bioinorganic chemistry, multi-electron redox chemistry, pharmaceutical, key intermediates for biochemical reactions, corrosion inhibitors, catalysts, inorganic and analytical chemistry) since it was first discovered [21-26]. SBs were synthesized from the condensation reaction between the amine and carbonyl compound (aldehyde or ketone) [27]. They could be represented as $\mathrm{RCH}=\mathrm{NR}$, where $\mathrm{R}$ is an organic substituent. Due to steric and electronic effects, the reaction of aldehydes is faster than ketones [28,29]. They have received great attention from researchers because of their ease of synthesis [30,31], low-cost preparation [11], great flexibility and diverse structural aspects [32,33]. Other than that, [34] and [22] reported that these SBs formed from aromatic aldehyde or aromatic ketones are more stable than aliphatic because of their effective conjugation. SBs have also been successfully used in electrochemical sensor studies. However, to date, there is very little study of free SBs as a recognition layer. One of the latest was reported by Wang et al. [35], which were functioned as a glucose sensor. Many of them were used as ligands or metal complexes for metal, membrane, forensic, pharmaceutical, or even environmental interest [36-42]. Moreover, the characteristics of aromatic SBs, which could enhance sensitivity and selectivity $[41,43]$ and good stability $[42,44]$, have been an add-up value.

Thus, herein we report the synthesis and characterization of three SBs with ethyl, methyl, or methoxy substituents. The obtained compounds might be potentially useful in electrochemical DNA sensor study in the future, with nitrile $(\mathrm{C} \equiv N)$ at another end binding with the working electrode.

\section{Materials and Methods}

\subsection{Materials and instrumentations.}

4-vinylaniline, 4-iodobenzonitrile, p-ethylbenzaldehyde, p-tolualdehyde and panisaldehyde (98\%) were purchased from Acros Organics; N, N-dimethylformamide and dichloromethane were from Fisher Scientific, while trimethylamine and ethanol absolute were purchased from Sigma-Aldrich, R\&M Chemicals and HmbG Chemicals, respectively. All chemicals were used without any further purification. Bis(triphenylphosphine)palladium chloride $\left(\mathrm{PdCl}_{2}\left(\mathrm{PPh}_{3}\right)_{2}\right)$ was used as a catalyst in Heck-cross coupling reaction and prepared with appropriate amounts of $5 \mathrm{mmol}$ palladium (II) chloride $\left(\mathrm{PdCl}_{2}\right)$ and $10.5 \mathrm{mmol}$ triphenylphosphine $\left(\mathrm{PPh}_{3}\right)$. Thin-layer chromatography (TLC) used was a plastic pre-coated plate of silica gel 60 F254, $0.25 \mathrm{~mm}$ thick (Merck KGaA) and silica gel 60 (particle size 0.063 $0.200 \mathrm{~mm}, 70-230$ mesh ASTM) was used for column chromatography. Infrared spectra were obtained with a Shimadzu IRTracer-100 Fourier Transform Infrared Spectrometer in the 4000$400 \mathrm{~cm}^{-1}$ region. UV-Vis spectra were recorded with a double beam Shimadzu UV-1800 spectrophotometer using acetonitrile solutions in $1.0 \mathrm{~cm}$ path length cuvette. Spectra of ${ }^{1} \mathrm{H}$ and ${ }^{13} \mathrm{C}$ nuclear magnetic resonance (NMR) were recorded on a Bruker Avance II 400 spectrophotometer in deuterated chloroform $\left(\mathrm{CDCl}_{3}-\mathrm{d}_{6}\right)$.

\subsection{Preparation of 4-(4-aminostyryl)benzonitrile (2).}

Synthesis of 2 was carried out according to the published procedure [22,45]. 4iodobenzonitrile $(1 \mathrm{~mol})$ was added to a mixture of $\mathrm{N}, \mathrm{N}$-dimethylformamide $(3 \mathrm{ml})$ and 4 vinylaniline (1 mol, $0.4 \mathrm{~g})$, trimethylamine $(3 \mathrm{ml})$ as base and bis(triphenylphosphine)palladium chloride $(40 \mathrm{mg})$ as catalyst in a three-neck round bottom 
flask. The resulting mixture was stirred well and refluxed for 24 hours at $70-80{ }^{\circ} \mathrm{C}$. The reaction progress was monitored by TLC. Later, the reaction mixture was filtered and thoroughly washed by dichloromethane. The solvent was evaporated by the rotary evaporator and the residue was purified by column chromatography.

\subsection{Preparation of imine derivatives $(2 a-2 c)$.}

In a Dean-stark flask, 1 mol of 4-(4-aminostyryl)benzonitrile 2 was dissolved in ethanol $(50 \mathrm{ml}$ ). Then, $0.1 \mathrm{ml}$ of aldehyde (p-ethylbenzaldehyde (a), p-tolualdehyde (b), or panisaldehyde (c) in ethanol $(10 \mathrm{ml})$ was added at $60{ }^{\circ} \mathrm{C}$. The reaction mixture was refluxed for 2 hours at $80^{\circ} \mathrm{C}$. Later, it was cooled down and the product was precipitated [46]. The yielded product was filtered off and recrystallized from hot acetonitrile [47]. Benzonitrile styryl imine derivatives $(\mathbf{2 a}, \mathbf{2 b}, \mathbf{2 c})$ produced were weighed and the percentage yield was recorded. Scheme 1 shows the experimental scheme to synthesis each compound.

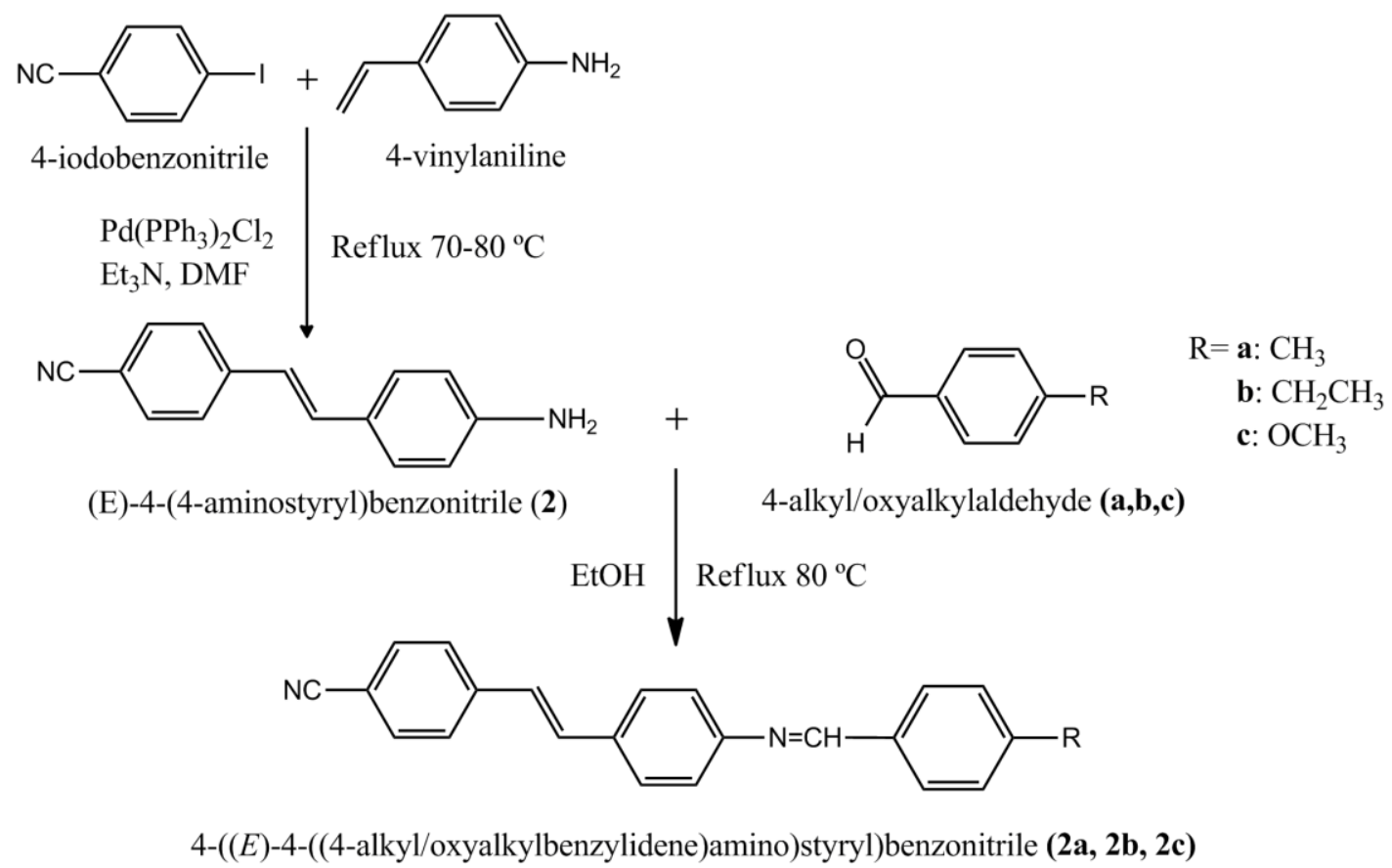

Scheme 1. Experimental scheme to synthesis each compound.

\section{Results and Discussion}

\subsection{Fourier Transform Infrared (FTIR).}

The FTIR spectra showed similar vibration types, except for the main functional group of every compound (Figure 1). The bands observed at $3464 \& 3367 \mathrm{~cm}^{-1}$ indicated the N-H stretching vibration of primary amine $\left(\mathrm{NH}_{2}\right)$ present at the end of compound $2[48,49]$. The higher-frequency band in the pair is due to the asymmetric vibration, whereas the lowerfrequency band results from a symmetric vibration of the primary amine [50,51]. This band is not observed in compounds $\mathbf{2 a}, \mathbf{2 b}$ and 2c. An absorption frequency higher than $3000 \mathrm{~cm}^{-1}$ usually implies the C-H stretching peaks. Since C-H stretching $\left(\mathrm{sp}^{2}\right.$ and $\left.\mathrm{sp}^{3}\right)$ bands of alkanes, alkenes and aromatic compounds appear in the same range, thus it may be difficult to differentiate between them. However, it can be differentiated based on bending and out-ofplane bands. Compounds 2a-2c showed a medium intensity $\mathrm{CH}_{3}$ bending band around 1366$1373 \mathrm{~cm}^{-1}$ [52], while only compound $\mathbf{2 a}$ has $\mathrm{CH}_{2}$ bending vibration band at $1458 \mathrm{~cm}^{-1}[52,53]$. 
This could even distinguish between those three imine derivatives. Meanwhile, the trans double bond of alkene was observed at $964-972 \mathrm{~cm}^{-1}$ and one strong band in the range of $837-850 \mathrm{~cm}^{-}$ ${ }^{1}$ indicates para-disubstituted rings of aromatic $\mathrm{CH}$ out-of-plane bending. These values are supported by [54]. Furthermore, the $\mathrm{C}=\mathrm{C}$ stretching bands for the aromatic ring usually appear in pairs at 1460 and $1600 \mathrm{~cm}^{-1}$ [55], outside the usual range where the $\mathrm{C}=\mathrm{C}$ appears for alkene $\left(1682 \mathrm{~cm}^{-1}\right)$. The $\mathrm{C}=\mathrm{C}$ stretch of alkene occurs vanishingly weak for symmetrically trans disubstituted double bonds [50]. Meanwhile, the nitrile $(\mathrm{C} \equiv \mathrm{N})$ group shows a sharp medium intensity band at $2222 \mathrm{~cm}^{-1}$ [56,57]. This aromatic nitrile absorbs radiations at lower frequencies due to the conjugation of the triple bond with the ring [50]. $\mathrm{C}=\mathrm{N}$ bond of an imine has $\mathrm{sp}^{2}$ carbon atom. They absorb in about the same range as a $\mathrm{C}=\mathrm{C}$ bond, but $\mathrm{C}=\mathrm{N}$ stretch of compounds 2a-2c ranges from $1681-1708 \mathrm{~cm}^{-1}[58]$ and is more intense than $\mathrm{C}=\mathrm{C}$ bond. Phenyl alkyl ether (C-O-C) of compound 2c shows two strong bands at 1024 (symmetric) \& 1253 (asymmetric) $\mathrm{cm}^{-1}[59,60]$, which were confirmed since ester and alcohol were absent in compound 2c (Scheme 1). Furthermore, it is more convincing when compared with the other compounds synthesized as only $\mathbf{2 c}$ is allowed to have C-O stretching bands.

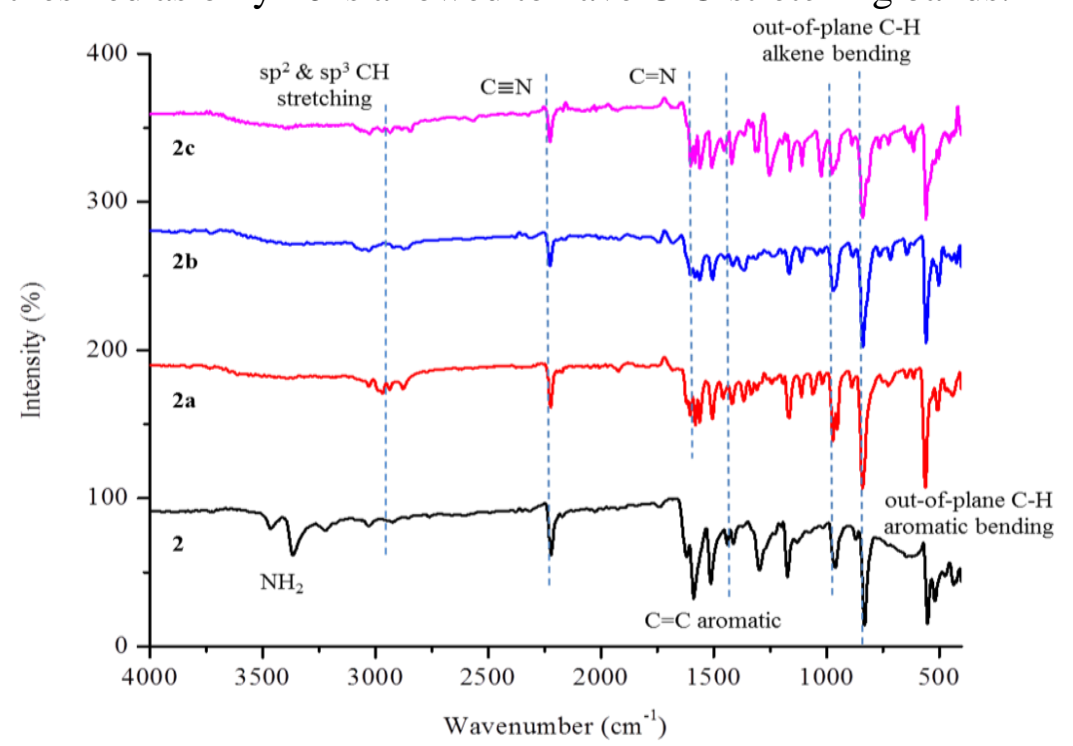

Figure 1. FTIR of 2, 2a-2c.

\subsection{UV-Visible spectroscopy.}

The incorporation of aromatic rings had extent the conjugation and thus increased the wavelength when comparing compound $\mathbf{2}$ with its Schiff-bases products (2a-2c), as supported by Hemavathi et al. [61]. $\pi \rightarrow \pi^{*}(240-276 \mathrm{~nm})$ was observed, indicating the presence of aromatic rings $[62,63]$. The electron energy levels become closer as the conjugation increase. Therefore, only small energy is needed to transition an electron from the occupied electronic energy level to the unoccupied level energy [50]. The peak observed at $355.5 \mathrm{~nm}$ is assigned to the $\pi-\pi *$ electronic transition of $\mathrm{C} \equiv \mathrm{N}$ chromophores. The extent of conjugation also affects hyperchromic absorption value by 2 folds $[50,64]$. The broadband at 355-360 nm could be assigned to azomethine with the transition of $n \rightarrow \pi^{*}[22,65,66]$. A bathochromic shift was observed at 350-360 nm when compared compound 2 with the Schiff-bases compounds (2a2c). This was caused by the electron-withdrawing or electron-donating ability of the Schiffbases substituents [67]. From the spectrum, the absorbance intensity increase with a longer alkyl length [68]. The summary of all data obtained is as shown in Table 1 and Figure 2. 
Table 1. UV-Vis of 2, 2a-2c.

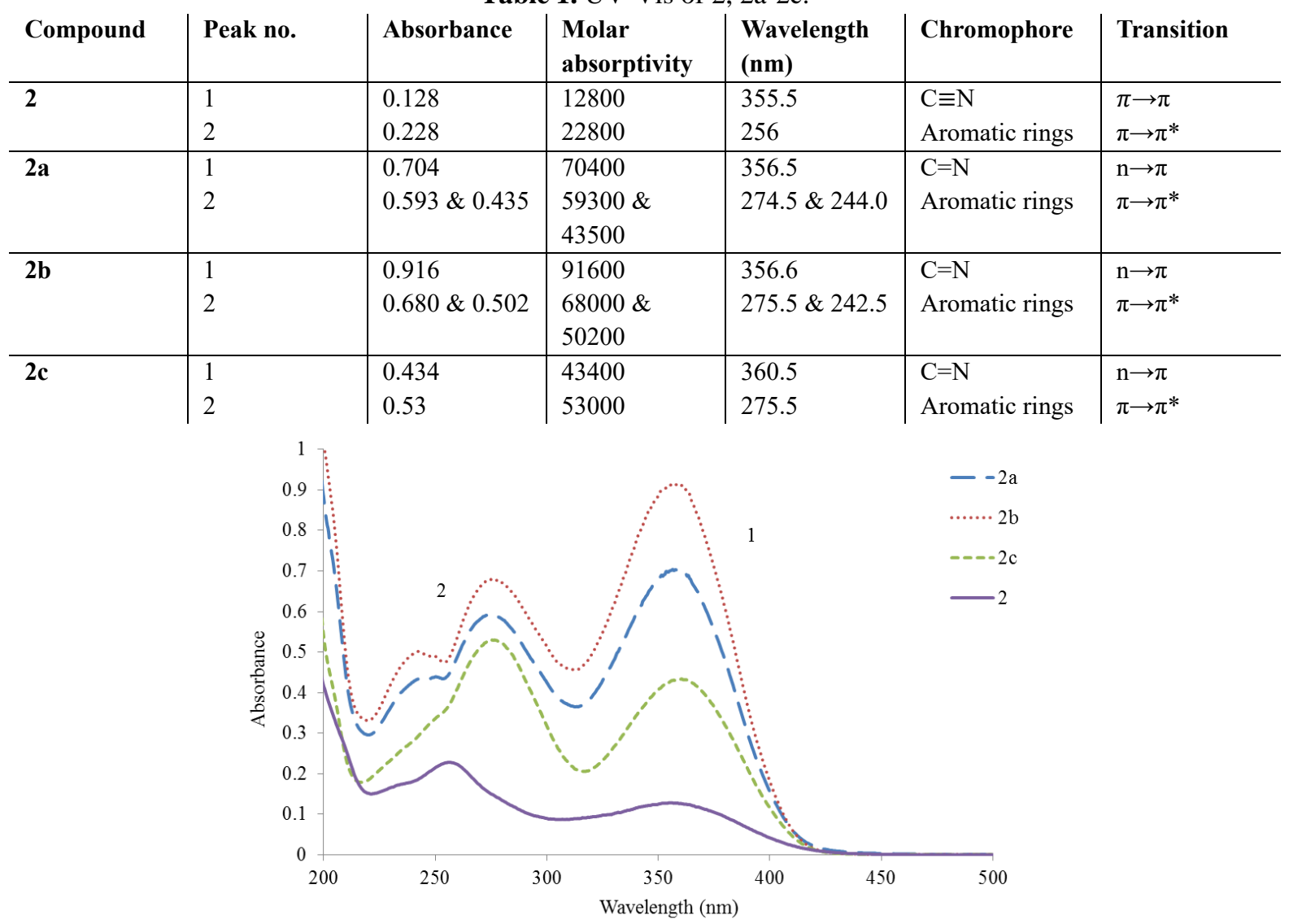

Figure 2. UV-Vis of 2, 2a-2c.

\subsection{Nuclear Magnetic Resonance (NMR).}

Table 2 represents the ${ }^{1} \mathrm{H}$ chemical shifts of compounds $\mathbf{2}$, 2a-2c. The spectra display a broad singlet signal of $\mathrm{NH}_{2}$ at $\delta 3.77 \mathrm{ppm}$ for compound 2, due to no direct hydrogen coupling on nitrogen to an adjacent carbon atom [50,69]. This finding was confirmed by the absence of this signal in compounds $\mathbf{2 a - 2 c}$ (Figure 3). Besides, in spectra 2a-2c, a sharp singlet imine (H$\mathrm{C}=\mathrm{N}$ ) signal was observed at $8.34-8.39 \mathrm{ppm}$. The moieties of a doublet-doublet signal of alkene $(\mathrm{H}-\mathrm{C}=\mathrm{C})$ were observed at 6.83-7.03 ppm and 7.07-7.17 ppm for all compounds. Aromatic protons of the benzene ring were identified at $6.62-7.80 \mathrm{ppm}$. All signals were in an almost similar region except for the downfield part. $\mathrm{CH}_{2}$ and $\mathrm{CH}_{3}$ of compound $\mathbf{2 a}$ appeared as a quartet at $2.68 \mathrm{ppm}$ and as triplets at $1.22 \mathrm{ppm}$, respectively.

Table 2. Chemical shifts (ppm) of ${ }^{1} \mathrm{H}$ NMR of 2-2c.

\begin{tabular}{l|l|l|l|l|l|l} 
Compound & NH2 & $\begin{array}{l}\text { C-H } \\
\text { (Aromatic) }\end{array}$ & $\begin{array}{l}\text { HC=C } \\
\text { (Alkene) }\end{array}$ & $\begin{array}{l}\text { CH=N } \\
\text { (Imine) }\end{array}$ & CH2 & CH3 \\
\hline $\mathbf{2}$ & 3.77 & $6.62,7.29$, & $6.83,7.07$ & - & - & - \\
& & $7.46,7.53$ & & & & \\
\hline $\mathbf{2 a}$ & - & $7.18,7.25$, & $7.02,7.15$ & 8.39 & 2.68 & 1.22 \\
& & $7.50,7.52$, & & & & \\
\hline $\mathbf{2 b}$ & - & $7.57,7.77$ & & & 2.36 \\
& & $7.19,7.23$, & $7.03,7.16$ & 8.38 & - & \\
\hline $\mathbf{2 c}$ & - & $7.58,7.74$ & & & & 3.81 \\
& & $6.93,7.14$, & $7.17,7.02$ & 8.34 & - &
\end{tabular}




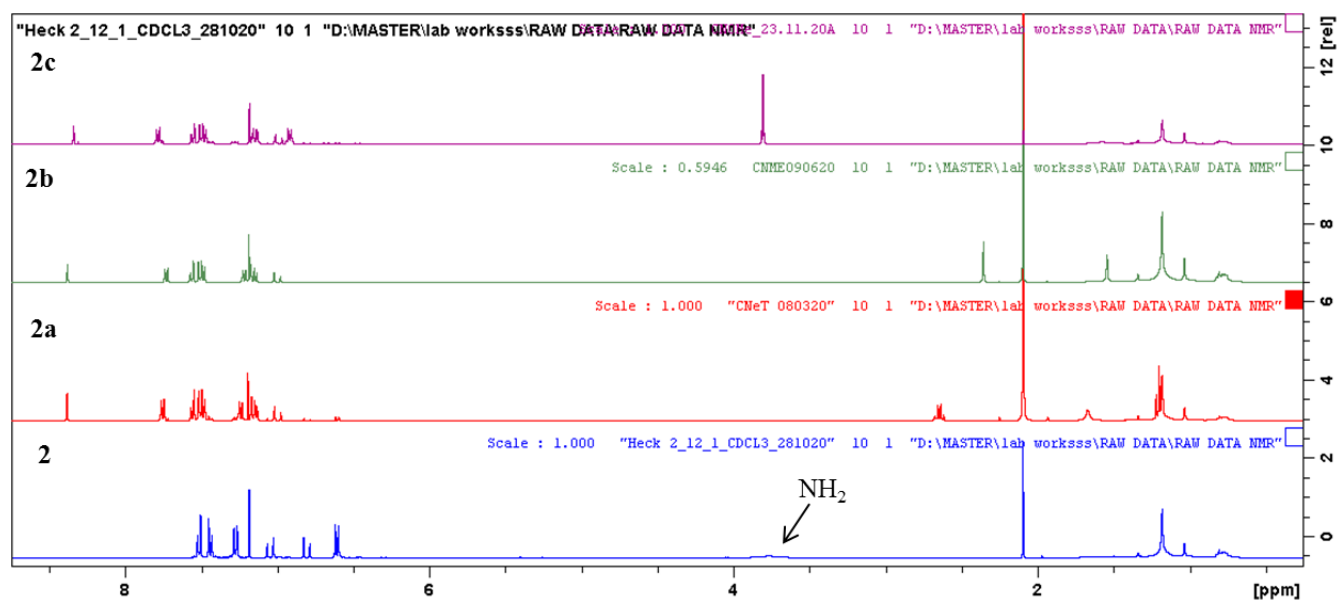

Figure 3. ${ }^{1} \mathrm{H}$ NMR spectra of 2-2c.

$\mathrm{CH}_{3}$ of compound $\mathbf{2 b}$ appeared as a sharp singlet at $2.36 \mathrm{ppm}$, while $\mathrm{CH}_{3}$ of compound $\mathbf{2 c}$ appeared as $3.81 \mathrm{ppm}$, slightly shifted to a higher field. This is because protons in the methyl group in compound $\mathbf{2 c}$ were deshielded by the oxygen as the electronegative atom [50,70].

The ${ }^{13} \mathrm{C}$ NMR of compounds $\mathbf{2}, \mathbf{2 a - 2}$ in $\mathrm{CDCl}_{3}$ were shown in Figure 4. The presence of a C-alkyl signal of compound $\mathbf{2 a}$ was identified at $14.33 \mathrm{ppm}$. The alkene $(\mathrm{C}=\mathrm{C})$ of $\mathbf{2 a - 2 \mathbf { c }}$ were discovered at 125.74-126.79 ppm and 124.94-126.08 ppm. However, only one signal at 121.87 ppm was observed for $\mathrm{C}=\mathrm{C}$ of compound 2 [71]. Meanwhile, the aromatic resonance of all synthesized compounds was found in the range 109.35-161.43 ppm and cyano $(\mathrm{C} \equiv \mathrm{N})$ in the range of 118.07-119.09 ppm [72,73]. The resonance at 159.37, 160.36 and 158.67 ppm of imine $(\mathrm{C}=\mathrm{N})$ confirmed the chemical structure of compounds 2a-2c. All chemical shifts observed were presented in Table 3.

Table 3. Chemical shifts (ppm) of ${ }^{13} \mathrm{C}$ NMR of 2, 2a-2c.

\begin{tabular}{|c|c|c|c|c|c|}
\hline Compound & $\mathrm{C} \equiv \mathbf{N}($ cyano $)$ & $\begin{array}{l}\text { C-C } \\
\text { (Aromatic) }\end{array}$ & $\begin{array}{l}\mathrm{C}=\mathrm{C} \\
\text { (Alkene) }\end{array}$ & $\mathrm{C}=\mathbf{N}$ (Imine) & C-C (Alkyl) \\
\hline 2 & 118.27 & $\begin{array}{l}114.10,125.33, \\
127.33,131.44, \\
108.54,125.78, \\
141.58,146.11\end{array}$ & - & 121.87 & - \\
\hline $2 \mathbf{a}$ & 118.07 & $\begin{array}{l}120.50,127.38, \\
130.89,127.99, \\
126.81,131.48, \\
109.36,132.93, \\
140.54,151.41, \\
132.72,147.44\end{array}$ & $\begin{array}{l}125.76 \\
125.03\end{array}$ & 159.37 & $14.33,27.96$ \\
\hline $2 b$ & 119.09 & $\begin{array}{l}121.54,128.92, \\
131.93,129.59, \\
127.85,132.52, \\
110.43,133.55, \\
133.97,141.97, \\
142.19,152.43\end{array}$ & $\begin{array}{l}126.79 \\
126.08\end{array}$ & 160.36 & 21.69 \\
\hline $2 c$ & 118.07 & $\begin{array}{l}113.24,120.50, \\
130.93,129.63, \\
126.82,131.48, \\
109.35,128.10, \\
132.75,140.97, \\
151.52,161.43\end{array}$ & $\begin{array}{l}125.74, \\
124.94\end{array}$ & 158.67 & 54.44 \\
\hline
\end{tabular}




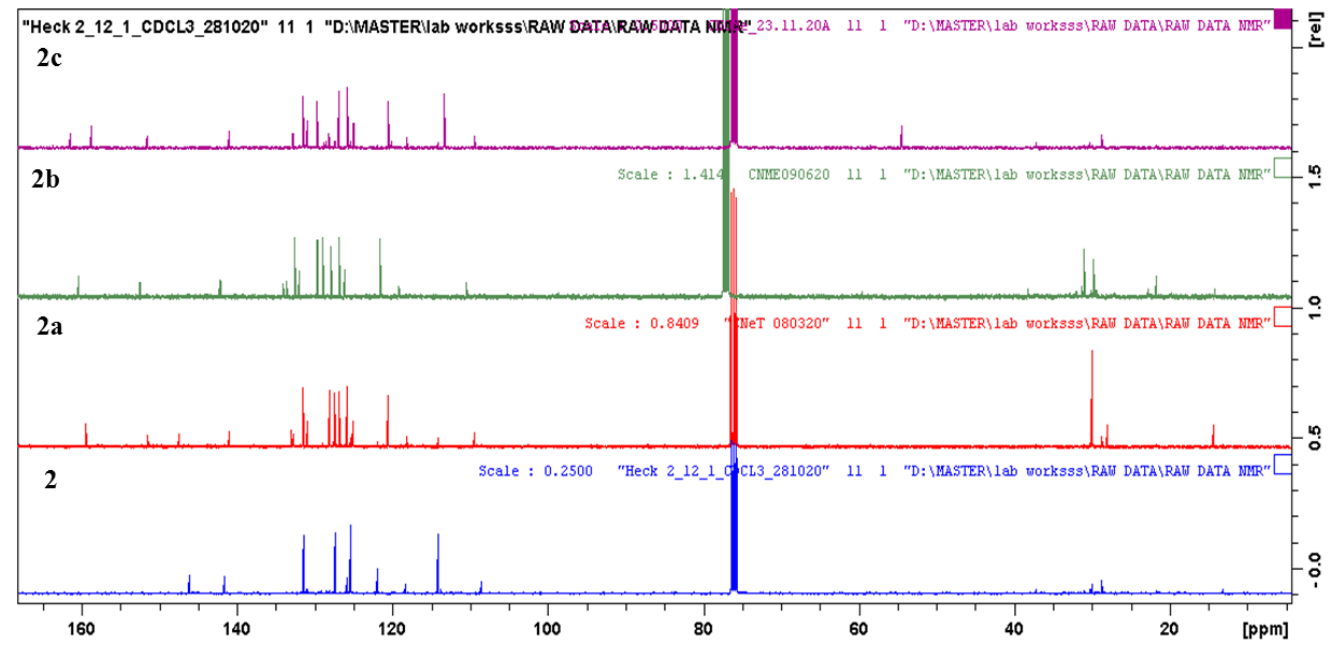

Figure 4. ${ }^{13} \mathrm{C}$ NMR spectra of 2-2c.

\section{Conclusions}

p-cyano Schiff base compounds using 4-(4-aminostyryl)benzonitrile with secondary aldehydes to develop future electrochemical DNA sensor spacer were synthesized. The resulting p-cyano Schiff base spacer structure was fully confirmed using IR spectroscopy, UVVis and NMR analysis. The prepared p-cyano Schiff base spacer was successfully synthesized by Heck and Schiff base reactions. As reported by many, aromatic Schiff base compounds are believed to be more stable and might be able to enhance the sensitivity and selectivity of the sensor. So the present work can overcome the limitation faced by alkanethiols and open up a new and potentially useful spacer in detecting DNA electrochemically.

\section{Funding}

This research was funded by the MINISTRY OF HIGHER EDUCATION (MOHE), grant number FRGS vot 59383 (FRGS/1/2015/SG01/UMT/02/3).

\section{Acknowledgments}

The authors would like to thank Universiti Malaysia Terengganu for the support and equipment provided.

\section{Conflicts of Interest}

The authors declare no conflict of interest. The funders had no role in the study's design, in the collection, analyses, or interpretation of data, in the writing of the manuscript, or in the decision to publish the results.

\section{References}

1. Patel, M.K.; Solanki, P.R.; Khandelwal, S.; Agrawal, V. V.; Ansari, S.G.; Malhotra, B.D. Self-assembled monolayer based electrochemical nucleic acid sensor for Vibrio cholerae detection. J. Phys. Conf. Ser. 2012, 358, https://doi.org/10.1088/1742-6596/358/1/012009.

2. Guo, Y.; Su, S.; Wei, X.; Zhong, Y.; Su, Y.; Huang, Q.; Fan, C.; He, Y. A silicon-based electrochemical sensor for highly sensitive, specific, label-free and real-time DNA detection. Nanotechnology 2013, 24, https://doi.org/10.1088/0957-4484/24/44/444012.

3. Rahman. M.M.; Lopa, N.S.; Kim, Y.J.; Choi, D.-K.; Lee, J.-J. Label-Free DNA Hybridization Detection by Poly(Thionine)-Gold Nanocomposite on Indium Tin Oxide Electrode. J. Electrochem. Soc. 2016, 163, B153- 
B157, https://doi.org/10.1149/2.0601605jes.

4. Kochana, J.; Starzec, K.; Wieczorek, M.; Knihnicki, P.; Góra, M.; Rokicińska, A.; Kościelniak, P.; Kuśtrowski, P. Study on self-assembled monolayer of functionalized thiol on gold electrode forming capacitive sensor for chromium(VI) determination. J. Solid State Electrochem. 2019, 7, 1463-1472, https://doi.org/10.1007/s10008-019-04236-2.

5. Brett, C.M.A.; Kresak, S.; Hianik, T.; Brett, A.M.O. Studies on self-assembled alkanethiol monolayers formed at applied potential on polyerystalline gold electrodes. Electroanalysis 2003, 15, 557-565, https://doi.org/10.1002/elan.200390069.

6. Yafeng, X. Electrochemical Properties of Alkanethiol Self-Assembled Monolayer on Gold, Doctor of Philosophy Degree, National University of Singapore, Singapore, 2004.

7. Lai, R.Y.; Seferos, D.S.; Heeger, A.J.; Bazan, G.C.; Plaxco, K.W. Comparison of the signaling and stability of electrochemical DNA sensors fabricated from 6- or 11-carbon self-assembled monolayers. Langmuir 2006, 22, 10796-10800, https://doi.org/10.1021/la0611817.

8. Henry, O.Y.F.; Sanchez, J.L.A.; O'Sullivan, C.K. Bipodal PEGylated alkanethiol for the enhanced electrochemical detection of genetic markers involved in breast cancer. Biosens. Bioelectron. 2010, 26, 15001506, https://doi.org/10.1016/j.bios.2010.07.095.

9. Calam, T.T.; Hasdemir, E. Comparative characterizations of self-assembled monolayers of 1,6-hexanedithiol and 1-hexanethiol formed on polycrystalline gold electrode. Comptes Rendus L'Academie Bulg. Des Sci. 2019, 72, 316-326, https://doi.org/10.7546/CRABS.2019.03.05.

10. Shaver, A.; Curtis, S.D.; Arroyo-Currás, N. Alkanethiol Monolayer End Groups Affect the Long-Term Operational Stability and Signaling of Electrochemical, Aptamer-Based Sensors in Biological Fluids. ACS Appl. Mater. Interfaces. 2020, 12, 11214-11223, https://doi.org/10.1021/acsami.9b22385.

11. Yusoff, H.M.; Hassan, N.; Ku Bulat, K.H. Theoretical and Experimental Approach Towards P-Cyano Stilbene Schiff Base as a Potential Linker in E-DNA Sensor. IOP Conf. Ser. Mater. Sci. Eng. 2018, 374, https://doi.org/10.1088/1757-899X/374/1/012086.

12. Lin, P.H.; Li, B.R. Antifouling strategies in advanced electrochemical sensors and biosensors. Analyst 2020, 145, 1110-1120, https://doi.org/10.1039/c9an02017a.

13. Lee, N.S.; Cho, G.; Shin, H.K.; Noh, J. Structural stability and phase transitions of octanethiol self-assembled monolayers on au(111) in ultrahigh vacuum. J. Nanosci. Nanotechnol. 2016, 16, 6388-6392, https://doi.org/10.1166/jnn.2016.12138.

14. Lee, H.E.; Kang, Y.O.; Choi, S.H. Electrochemical-DNA biosensor development based on a modified carbon electrode with gold nanoparticles for influenza a (H1N1) detection: Effect of spacer. Int. J. Electrochem. Sci. 2014, 9, 6793-6808.

15. Vericat, C.; Vela, M.E.; Benitez, G.; Carro, P.; Salvarezza, R.C. Self-assembled monolayers of thiols and dithiols on gold: new challenges for a well-known system. Chem. Soc. Rev. 2010, 39, 1805-1834, https://doi.org/10.1039/b907301a.

16. Crudden, C.M.; Horton, J.H.; Narouz, M.R.; Li, Z.; Smith, C.A.; Munro, K.; Baddeley, C.J.; Larrea, C.R.; Drevniok, B.; Thanabalasingam, B.; McLean, A.B.; Zenkina, O. V.; Ebralidze, I.I.; She, Z.; Kraatz, H.B.; Mosey, N.J.; Saunders, L.N.; Yagi, A. Simple direct formation of self-assembled N-heterocyclic carbene monolayers on gold and their application in biosensing. Nat. Commun. 2016, 7, 1-7, https://doi.org/10.1038/ncomms12654.

17. Ahmadzadeh-Raji, M.; Ghafar-Zadeh, E.; Amouabediny, G. An optically-transparent aptamer-based detection system for colon cancer applications using gold nanoparticles electrodeposited on indium tin oxide. Sensors 2016, 16, https://doi.org/10.3390/s16071071.

18. Phares, N.; White, R.J.; Plaxco, K.W. Improving the Stability and Sensing of Electrochemical Biosensors by Employing Trithiol-Anchoring Groups in a Six- carbon Self-assembled Monolayer. Anal. Chem 2009, 81, 1095-1100, https://doi.org/10.1021/ac8021983.

19. Kang, S.; Byeon, S.E.; Yoon, H.J. N-Heterocyclic Carbene Anchors in Electronics Applications. Bull. Korean Chem. Soc. 2021, 1-12, https://doi.org/10.1002/bkcs.12261.

20. Krzykawska, A.; Wróbel, M.; Kozieł, K.; Cyganik, P. N-Heterocyclic Carbenes for the Self-Assembly of Thin and Highly Insulating Monolayers with High Quality and Stability. ACS Nano 2020, 14, 6043-6057, https://doi.org/10.1021/acsnano.0c01733.

21. Karamunge, K.G.; Vibhute, Y.B. Synthesis and antimicrobial activity of some new Schiff bases. J. Phys. Conf. Ser. 2013, 423, https://doi.org/10.1088/1742-6596/423/1/012006.

22. Norhafiefa, H.; Yusoff, H.M.; Rahamathullah, R. Synthesis and characterization of alkoxy substituted p- 
cyano stilbene schiff bases. IOP Conf. Ser. Mater. Sci. Eng. 2018, 440, https://doi.org/10.1088/1757899X/440/1/012016.

23. K., M.; P., T.; DB, K. Synthesis and Characterization of Schiff base m-nitro aniline and their complexes. Res. J. Chem. Sci 2015, 5, 2231-606, http://www.isca.in/rjcs/Archives/v5/i5/8.ISCA-RJCS-2015-060.pdf.

24. Menaka, R.; Subhashini, S. Chitosan Schiff base as effective corrosion inhibitor for mild steel in acid medium. Polym. Int. 2017, 66, 349-358, https://doi.org/10.1002/pi.5245.

25. Sessler, J.L.; Sibert, J.W. On the synthesis of unsymmetrical bis(macrocyclic) ligands. Tetrahedron 1993, 49, 8727-8738, https://doi.org/10.1016/S0040-4020(01)81895-0.

26. Alshaheri, A.A.; Tahir, M.I.M.; Rahman, M.B.A.; Begum, T.; Saleh, T.A. Synthesis, characterisation and catalytic activity of dithiocarbazate Schiff Base Complexes in Oxidation of Cyclohexane. J. Mol. Liq. 2017, 240, 486-496, https://doi.org/http://dx.doi.org/10.1016/j.molliq.2017.05.081.

27. Schiff, H. Mittheilungen aus dem Universitätslaboratorium in Pisa: Eine neue Reihe organischer Basen. Justus Liebigs Ann. Chem. 1864, 131, 118-119, https://doi.org/10.1002/jlac.18641310113.

28. Berhanu, A.L.; Mohiuddin, G. I.; Malik, A.K.; Aulakh, J.S.; Kumar, V.; Kim, K.H. A review of the applications of Schiff bases as optical chemical sensors. TrAC - Trends Anal. Chem. 2019, 116, 74-91, https://doi.org/10.1016/j.trac.2019.04.025.

29. Wang W.; Lu, K.; Qin, Y.; Yao, W.; Yuan, D.; Pullarkat, S.A.; Xu, L.; Ma, M. Grignard reagents-catalyzed hydroboration of aldehydes and ketones. Tetrahedron 2020, 76, https://doi.org/10.1016/j.tet.2020.131145.

30. Abu-Dief, A.M.; Mohamed, I.M.A. A review on versatile applications of transition metal complexes incorporating Schiff bases. Beni-Suef Univ. J. Basic Appl. Sci. 2015, 4, 119-133, https://doi.org/10.1016/j.bjbas.2015.05.004.

31. Gondia, N.K.; Sharma, S.K.; Optical Characterization of toluene-based Schiff base metal complexes for optoelectronic applications. J. Mater. Sci. Mater. Electron. 2020, 31, 22442-22451, https://doi.org/10.1007/s10854-020-04745-1.

32. Toliwal, S.; Jadav K.; Patel, K. Synthesis and biological evaluation of fatty hydrazides of by-products of oil processing industry. Indian J. Pharm. Sci. 2009, 71, 144-148, https://doi.org/10.4103/0250-474X.54282.

33. Bayeh, Y.; Mohammed, F.; Gebrezgiabher, M.; Elemo, F.; Getachew, M. Synthesis , Characterization and Antibacterial Activities of Polydentate Schiff Bases, Based on Salicylaldehyde. Adv. Biol. Chem. 2020, 10, 127-139, https://doi.org/10.4236/abc.2020.105010.

34. Hassan, N.; Yusoff, H.M. Synthesis and Characterization of 4-Propoxybenzaldehyde Substituted Heck-Schiff Base Compound as Spacer in Electrochemical DNA Sensor. Malaysian J. Anal. Sci 2019, 23, 763-770, https://doi.org/10.17576/mjas-2019-2305-01.

35. Wang, L.; Xu, M.; Xie, Y.; Qian, C.; Ma, W.; Wang, L.; Song, Y. Ratiometric electrochemical glucose sensor based on electroactive Schiff base polymers. Sensors Actuators, B Chem. 2019, 285, 264-270, https://doi.org/10.1016/j.snb.2019.01.061.

36. Singh, L.P.; Bhatnagar, J.M. Copper(II) selective electrochemical sensor based on Schiff Base complexes. Talanta. 2004, 64, 313-319, https://doi.org/10.1016/j.talanta.2004.02.020.

37. Gupta, V.K.; Singh, A.K.; Gupta, B. A cerium(III) selective polyvinyl chloride membrane sensor based on a Schiff base complex of N,N'-bis[2-(salicylideneamino)ethyl]ethane-1,2-diamine. Anal. Chim. Acta. 2006, 575, 198-204, https://doi.org/10.1016/j.aca.2006.05.090.

38. Nourifard, F.; Payehghadr, M. Conductometric studies and application of new Schiff base ligand as carbon paste electrode modifier for mercury and cadmium determination. Int. J. Environ. Anal. Chem. 2016, 96, 552-567, https://doi.org/10.1080/03067319.2016.1172219.

39. Kumar, A.; Vashistha, V.K.; Tevatia, P.; Singh, R. Electrochemical studies of DNA interaction and antimicrobial activities of MnII, FeIII, CoII and NiII Schiff base tetraazamacrocyclic complexes. Spectrochim. Acta - Part A Mol. Biomol. Spectrosc. 2017, 176, 123-133, https://doi.org/10.1016/j.saa.2016.12.011.

40. Pogány, L.; Moncol, J.; Gál, M.; Šalitroš, I.; Boča, R. Four cobalt(III) Schiff base complexes - Structural, spectroscopic and electrochemical studies. Inorganica Chim. Acta. 2017, 462, 23-29, https://doi.org/10.1016/j.ica.2017.03.001.

41. Rauf, A.; Shah, A.; Khan, A.A.; Shah, A.H.; Abbasi, R.; Qureshi, I.Z.; Ali, S. Synthesis, pH dependent photometric and electrochemical investigation, redox mechanism and biological applications of novel Schiff base and its metallic derivatives. Spectrochim. Acta - Part A Mol. Biomol. Spectrosc. 2017, 176, 155-167, https://doi.org/10.1016/j.saa.2017.01.018.

42. Oiye, É.N.; Ribeiro, M.F.M.; Katayama, J.M.T.; Tadini, M.C.; Balbino, M.A.; Eleotério, I.C.; Magalhães, J.; 
Castro, A.S.; Silva, R.S.M.; da Cruz Júnior, J.W.; Dockal, E.R.; de Oliveira, M.F. Electrochemical Sensors Containing Schiff Bases and their Transition Metal Complexes to Detect Analytes of Forensic, Pharmaceutical and Environmental Interest. A Review. Crit. Rev. Anal. Chem. 2019, 49, 488-509, https://doi.org/10.1080/10408347.2018.1561242.

43. Manna, A.K.; Sahu, M.; Rout, K.; Das, U.K.; Patra, G.K. A highly selective novel multiple amide based Schiff base optical chemosensor for rapid detection of $\mathrm{Cu} 2+$ and its applications in real sample analysis, molecular logic gate and smart phone. Microchem. J. 2020, 157, 104860, https://doi.org/10.1016/j.microc.2020.104860.

44. Dong, S.; Zhao, R.; Zhu, J.; Lu, X.; Li, Y.; Qiu, S.; Jia, L.; Jiao, X.; Song, S.; Fan, C.; Hao, R.Z.; Song, H. B. Electrochemical DNA biosensor based on a tetrahedral nanostructure probe for the detection of avian influenza A (H7N9) virus. ACS Appl. Mater. Interfaces. 2015, 7, 8834-8842, https://doi.org/10.1021/acsami.5b01438.

45. Hassan, N.; Yusoff, H.M.; Shafawati, S.M.T. Synthesis and characterization of p-nitro stilbene Schiff base as a potential linker in E-DNA. ACM Int. Conf. Proceeding Ser. 2018, 103-107, https://doi.org/10.1145/3208955.3208967.

46. Mobinikhaledi, A.; Jabbarpour, M.; Hamta, A. Synthesis of Some Novel and Biologically Active Schiff Bases Bearing A 1,3,4-Thiadiazole Moiety Under Acidic and PTC Conditions. J. Chil. Chem. Soc. 2011, 56, 812814, https://doi.org/10.4067/S0717-97072011000300020.

47. Ageshina, A.A.; Uvarova, M.A.; Nefedov, S.E. Structure of cobalt(II) cymantrenecarboxylates prepared by recrystallization from methanol, THF, and acetonitrile. Russ. J. Inorg. Chem. 60 2015, 1218-1224, https://doi.org/10.1134/S0036023615100022.

48. Izham, N.Z.M.; Yusoff, H.M.; Bhat, I.U.H.; Endo, T.; Fukumura, H.; Kwon, E.; Yoshida, S.I.; Asari, A.; Osman, U.M.; Yusof, M.S.M. Data on synthesis and characterization of new p-nitro stilbene Schiff bases derivatives as an electrochemical DNA potential spacer. Data Br. 2020, 30, https://doi.org/10.1016/j.dib.2020.105568.

49. Bashir, R.A.; Mukhtar, Y.; Tukur, S.; Ahmad, A.J.; Kubau, F.A.; Raiya, A.B.; Iliyasu, I.; Bello, R.F. Preliminary Phytochemical Screening and Fourier Transform Infrared Spectroscopy (FTIR) Analysis of the Leaf and Stem Bark Extracts of Khaya senegalensis. FUW Trends Sci. Technol. J. 2020, 5, 496-499.

50. Pavia, D.L.; Lampman, G.M.; Kriz, G.S.; Vyvyan, J.R. Introduction to Spectroscopy: 4th Edition, 4th ed., Brooks/Cole, Cengange Learning, California, 2009.

51. Khandelwal, V.M.; Undre, P.B.; Saif, F.A.; Alameen, A.S.; Yaseen, S.A.; Patil, S.S.; Khirade, P.W. Investigation of intermolecular interactions between formamide-dimethyl amino ethanol binary mixtures through dielectric relaxation and FTIR study. AIP Conf. Proc. 2020, 2244, https://doi.org/10.1063/5.0009071.

52. Amit, Jamwal, R.; Kumari, S.; Dhaulaniya, A.S.; Balan, B.; Singh, D.K. Application of ATR-FTIR spectroscopy along with regression modelling for the detection of adulteration of virgin coconut oil with paraffin oil. LWT- Food Sci. Technol. 2020, 118, 108754, https://doi.org/10.1016/j.lwt.2019.108754.

53. Hussain, S.M.S.; Kamal, M.S.; Murtaza, M.; Effect of aromatic spacer groups and counterions on aqueous micellar and thermal properties of the synthesized quaternary ammonium gemini surfactants. J. Mol. Liq. 2019, 296, https://doi.org/10.1016/j.molliq.2019.111837.

54. Easmin, S.; Zaidul, I.S.M.; Ghafoor, K.; Ferdosh, S.; Jaffri, J.; Ali, M.E.; Mirhosseini, H.; Al-Juhaimi, F.Y.; Perumal, V.; Khatib, A. Rapid investigation of $\alpha$-glucosidase inhibitory activity of Phaleria macrocarpa extracts using FTIR-ATR based fingerprinting. J. Food Drug Anal. 2017, 25, 306-315, https://doi.org/10.1016/j.jfda.2016.09.007.

55. Longo, S.; Capuani, S.; Corsaro, C.; Fazio, E. Silver fir characterized by micro-imaging NMR and FTIR spectroscopy. IOP Conf. Ser. Mater. Sci. Eng. 2020, 777, https://doi.org/10.1088/1757-899X/777/1/012004.

56. Tan, H.; Kong, P.; Zhang, R.; Gao, M.; Liu, M.; Gu, X.; Liu, W.; Zheng, Z. Controllable generation of reactive oxygen species on cyano group modified carbon nitride for selective epoxidation of styrene. Innov. 2021, 2, 100089, https://doi.org/10.1016/j.xinn.2021.100089.

57. Wu, C.J.; Tong, L.F.; Zhang, W.X.; Liu, X.B. Synthesis, characterization, and properties of poly (arylene ether nitrile) with high crystallinity and high molecular weight. J. Phys. Chem. Solids. 2021, 154, 109945, https://doi.org/10.1016/j.jpcs.2021.109945.

58. Ommenya, F.K.; Nyawade, E. A.; Andala, D. M.; Kinyua, J. Synthesis, Characterization and Antibacterial Activity of Schiff Base, 4-Chloro-2-\{(E)-[(4-Fluorophenyl)imino]methyl $\}$ phenol Metal (II) Complexes. J. Chem. 2020, 2020, https://doi.org/10.1155/2020/1745236.

59. Tamboli, A.B.; Maldar, N.N. Synthesis and characterization of processable aromatic poly(ether ether ketone 
amide)s modified by phenoxy and 1,3 ketone moiety linkages. Polym. Bull. 2020, 77, 6591-6605, https://doi.org/10.1007/s00289-019-03093-3.

60. Nair, V.P.; Parvathy, A.J. FTIR Spectroscopic Studies on Strobilanthes Ciliatus Nees (Bremek). Gyanshauryam, International Scientific Refereed Research Journal 2020, 3, 72-76.

61. Hemavathi, B.; Akash, S.; Shanmukappagouda, Kusuma, J.; Devaiah, T.C.; Shwetharani, R.; Balakrishna, R.G.; Ahipa, T.N. New 2-methoxy-4,6-bis(4-(4-nitrostyryl)phenyl)nicotinonitrile: Synthesis, characterization and DSSC study. J. Photochem. Photobiol. A Chem. 2019, 377, 75-79, https://doi.org/10.1016/j.jphotochem.2019.03.032.

62. Dueke-Eze, Fasina, T.M.; Idika, N. Synthesis, electronic spectra and inhibitory study of some Salicylaldehyde Schiff bases of 2-aminopyridine. African J. Pure Appl. Chem. 2011, 5, 13-18, https://doi.org/10.5897/AJPAC.9000160.

63. Yusoff, H.M.; Rzeźnicka, I.I.; Hoshi, H.; Kajimoto, S.; Horimoto, N.N.; Sogawa, K.; Fukumura, H. Excitation Energy Migration in Yellow Fluorescent Protein (Citrine) Layers Adsorbed on Modified Giold Surfaces. Appl. Surf. Sci. 2013, 280, 776-782, https://doi.org/10.1016/j.apsusc.2013.05.060.

64. Milián-Medina, B.; Gierschner, J. “Though It Be but Little, It Is Fierce”: Excited State Engineering of Conjugated Organic Materials by Fluorination. J. Phys. Chem. Lett. 2017, 8, 91-101, https://doi.org/10.1021/acs.jpclett.6b02495.

65. Iftikhar, B.; Javed, K.; Khan, M.S.U.; Akhter, Z.; Mirza, B.; Mckee, V. Synthesis, characterization and biological assay of Salicylaldehyde Schiff base $\mathrm{Cu}(\mathrm{II})$ complexes and their precursors. J. Mol. Struct. 2018, 1155, 337-348, https://doi.org/10.1016/j.molstruc.2017.11.022.

66. Talip, R.A.A.; Tay, M.G.; Hashim, H.F. Synthesis, Characterization and Antibacterial Activities of Hydrazone Schiff Base Compounds and Its Derivatives. Malaysian J. Anal. Sci. 2017, 21, 1168-1175, https://doi.org/10.17576/mjas-2017-2105-21.

67. Fang, Z.; Cao, C. Effect of molecular conformation on spectroscopic properties of symmetrical Schiff bases derived from 1,4-phenylenediamine. J. Mol. Struct. 2013, 1036, 447-451, https://doi.org/10.1016/j.molstruc.2012.12.014.

68. Sharma, N.K.; Singh, M.; Bhattarai, A. Hydrophobic study of increasing alkyl chain length of platinum surfactant complexes: synthesis, characterization, micellization, thermodynamics, thermogravimetrics and surface morphology. RSC Adv. 2016, 6, 90607-90623, https://doi.org/10.1039/C6RA20330B.

69. Güzel, E.; Arslan, B.S.; Çlkrlkçl, K.; Ergün, A.; Gençer, N.; Arslan, O.; Şişman, I.; Nebioğlu, M. Synthesis, in vitro inhibition effect of novel phthalocyanine complexes as carbonic anhydrase and paraoxonase enzyme inhibitors. J. Porphyr. Phthalocyanines. 2020, 24, 1047-1053, https://doi.org/10.1142/S1088424620500170.

70. Hagar, M.; Ahmed, H.A.; Aouad, M.R. Mesomorphic and DFT diversity of Schiff base derivatives bearing $\begin{array}{llllll}\text { protruded methoxy } \text { groups. } & \text { Liq. }\end{array}$ https://doi.org/10.1080/02678292.2020.1764642.

71. Rădulescu-Grad, M.E.; Visa, A.; Milea, M.S.; Lazău, R.I.; Popa, S.; Funar-Timofei, S. Synthesis, spectral characterization, and theoretical investigations of a new azo-stilbene dye for acrylic resins. J. Mol. Struct. 2020, 1217, https://doi.org/10.1016/j.molstruc.2020.128380.

72. Rizk, S.A.; El-Naggar, A.M.; El-Badawy, A.A. Synthesis, spectroscopic characterization and computational chemical study of 5-cyano-2-thiouracil derivatives as potential antimicrobial agents. J. Mol. Struct. 2018, 1155, 720-733, https://doi.org/10.1016/j.molstruc.2017.11.066.

73. Kharas, G.B.; Shinde, N.; Jody, J.K.; Mosher, E.K.; Kaur, N.; Oriol, A.A.R.; Perez, D.M.; Ranganathan,. R.; Renteria, A.; Rydbom, T.A.; Yeager, C.; Schjerven, W.S. Synthesis and styrene copolymerization of novel trisubstituted ethylenes: 3. alkoxy ring-substituted isopropyl 2-cyano-3-phenyl-2-propenoates. Des. Monomers Polym. 2018, 21, 163-171, https://doi.org/10.1080/15685551.2018.1531961. 